\title{
ANALISIS KELAYAKAN BUDIDAYA IKAN GURAME DI DESA KEDUNG REJO BUAY MADANG TIMUR KABUPATEN OKU TIMUR
}

\author{
(Yudi Zuriah)
}

\begin{abstract}
The objectives of this research are: (1) To calculate the cost, income and income earned by farmers in gouramy cultivation in every production process, (2) To analyze the feasibility of gouramy culture in Kedung Rejo Village Buay Madang Timur OKU Timur. This research was conducted in Kedung Rejo Village, Buay Madang Timur Sub-district, East OKU Regency. Selection of places chosen purposively with the consideration that the village of Kedung Rejo including the village that some farmers there who cultivate gourami. The study was conducted in February 2014. The study found that the total production cost incurred in gouramy fish culture amounted to $R p$ 19,316,827.00 per process, receipt during one production process of $R p$ 35,020,333.00, so the income received was Amounting to $R p$ 15.703.507,00 per process. The $R / C$ ratio is 1.77 indicating the profitability of the carp cultivation and the value of $N P V$ is Rp 20,871,523, the IRR value is $42 \%$ and the value of Net B / C is 1.79 which shows the cultivation of a proper gouramy (Feasible) to be developed.
\end{abstract}

Key Words : Feasibility Analysis, Business Feasibility Study, Gouramy Fish Cultivation, and Income.

\section{PENDAHULUAN}

\section{A. Latar Belakang}

Ikan gurami (Oshpronemus Gauramy, Lacepede) merupakan ikan asli indonesia dan berasal dari perairan daerah Jawa Barat. Ikan ini merupakan salah satu komoditi perikanan air tawar yang cukup penting apabila dilihat dari permintaanya yang cukup besar dan harganya relatif tinggi dibandingkan dengan ikan air tawar lainya seperti ikan mas, nila, tambakan dan tawes,dan merupakan salah satu sumber protein yang cukup tinggi. Bagi masyarakat umum, ikan ini dipandangsebagai salah satu ikan bergengsi dan biasanya disajikan pada acara-acara yang dianggap penting. Oleh sebab itu, tidak mengherankan apabila ikan gurami menjadi salah satu komoditi unggulan disektor perikanan air tawar (Sitanggang, 1999).

Umumnya budidaya ikan gurami masih dilaksanakan oleh masyarakat dengan teknologi semi intensif. Masa pemeliharaanya relatif lama sehingga dilakukan dengan beberapa tahap pembesaran, dimana pada masing-masing tahap menghasilkan produk yang dapat dipasarkan secara tersendiri (Sumantadinata, 1981 dalam Tim Karya Tani Mandiri, 2009).

Pasar ikan gurami mengandalkan pada pasar domestik. Namun demikian prospek bisnisnya cukup menjajikan mengingat permintaan dari masyarakat yang cukup besar. Ikan gurami lebih digemari dijual dalam keadaan hidup atau segar,dan biasanya harganya juga lebih tinggi dalam keadaan hidup, belum diperoleh data mengenai diversifikasi produk olahan ikan ini kecuali bentuk fillet (Hernanto, 1996).

Peranan Balai Benih Ikan dalam rangka pengembangan ikan gurami dilaksanakan antara lain berupa penyediaan induk dan benih unggul dan pengenalan teknologi budidaya secara intensif kepada pembudidaya ikan. Namun demikian, langkah pengembangan selanjutnya yang masih perlu dianggap penting adalah aspek pemasaran baik dipasar domestik maupun pasar ekspor (Departemen Kelautan dan Perikanan, 2010).

Pemerintah berupaya keras guna mendorong dan menumbuhkan minat dari petani dan wirausahawan ikan agar tertarik untuk mengusahakan dan mengembangkan pembenihan dan budidaya ikan gurami yakni dengan melakukan pembinaan dan penyuluhan secara intensif dan benar kepada petani perikanan melalui badan dan dinas terkait guna menerapkan pola pembenihan dan budidaya yang lebih baik dan tepat (Sumantadinata, 1981 dalam Tim Karya Tani Mandiri, 2009).

Propinsi Sumatera Selatan merupakan wilayah yang memiliki perairanan yang cukup luas dan sangat potensial untuk membudidayakan berbagai jenis komoditas ikan air tawar. Salah satu komoditas ai $r$ tawat yang berpotensi adalah ikan gurami. Ikan gurami merupakan salah satu jenis ikan air tawar yang memiliki nilai ekonomi tinggi. Ikan ini sudah banyak dibudidayakan secara komersial oleh masyarakat Indonesia, khususnya di pulau Sumatera. Wilayah kawasan pengembangan dan budidaya ikan gurami di Provinsi Sumatera Selatan terdapat dibeberapa kabupaten, seperti : Kabupaten Lubuk Linggau, 
Kabupaten Pagaralam, Kabupaten OKU Selatan dan Kabupaten OKU Timur.

Kabupaten OKU Timur adalah salah satu kabupaten di Sumatera Selatan yang turut serta dalam mensukseskan perikanan Sumatera Selatan. Kurang lebih $60 \%$ desa di Kabupaten OKU Timur memiliki tambak/kolam ikan dengan berbagai jenis kegiatan budidaya ikan, baik itu dari pembibitan, pembesaran dan penampungan. Jenis ikannya pun beragam seperti : Lele Sangkuriang, Gurami, Mujair, Patin, Ikan Emas dan jenis ikan lainya.

Desa Kedung Rejo merupakan salah satu desa yang ada di Kecamatan Buay Madang Timur yang sebagian penduduknya melakukan budidaya ikan gurami. Budidaya ikan gurami ini mampu menggerakkan roda perekonomian di Desa Kedung Rejo dan petani memperoleh pendapatan yang dapat meningkatkan kesejahteraan keluarga.

\section{B. Rumusan Masalah}

1. Berapa besar biaya, penerimaan dan pendapatan yang diperoleh oleh petani dalam budidaya ikan gurami di Desa Kedung Rejo Buay Madang Timur OKU Timur.

2. Apakah usaha budidaya ikan gurami di Desa Kedung Rejo Buay Madang Timur OKU Timur layak untuk dikembangkan.

\section{Tujuan dan Kegunaan}

1. Untuk menghitung besarnya biaya, penerimaan dan pendapatan yang diperoleh petani dalam budidaya ikan gurami dalam setiap proses produksi.

2. Untuk menganalisis kelayakan budidaya ikan gurami di Desa Kedung Rejo Buay Madang Timur OKU Timur.

\section{Model Pendekatan}

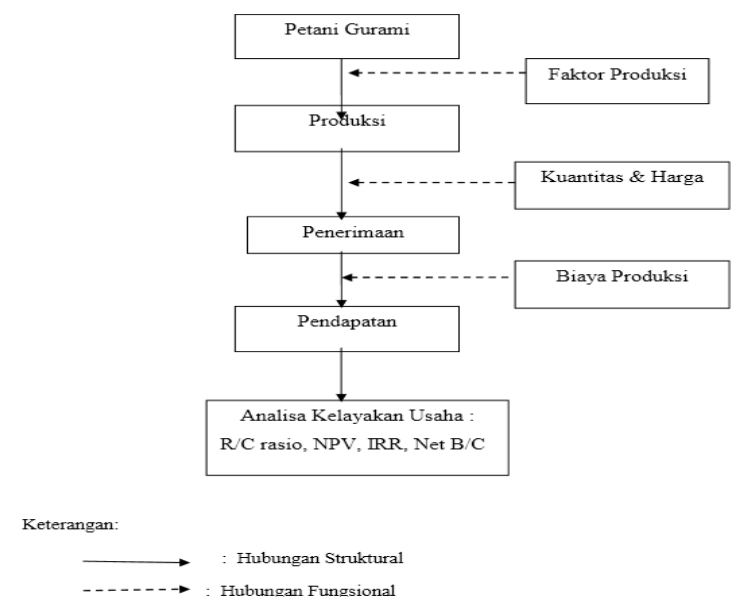

Gambar 1. Model pendekatan penelitian secara diagramatik

\section{METODOLOGI PENELITIAN}

\section{A. Tempat dan Waktu}

Penelitian telah dilaksanakan di Desa Kedung Rejo Kecamatan Buay Madang Timur Kabupaten OKU Timur. Pemilihan tempat dipilih secara sengaja (purposive) dengan pertimbangan bahwa Desa Kedung Rejo termasuk desa yang sebagian petaninya ada yang membudidayakan ikan gurami. Penelitian telah dilaksanakan pada bulan Februari 2014.

\section{B. Metode Penelitian}

Metode Penelitian yang digunakan dalam penelitian ini adalah metode survei, metode survei yaitu metode penelitian dimana peneliti mengunjungi dan mengambil fakta-fakta, mencari keterangan-keterangan secara faktual.

\section{Metode Penarikan Contoh}

Metode penarikan contoh yang digunakan adalah metode sensus, dimana semua elemen memiliki kesempatan untuk dijadikan contoh (sampel). Dalam Penelitian ini sampel berjumlah 15 orang dari 15 anggota populasi. Sampel yang diambil adalah semua petani yang membudidayakan ikan gurami di Desa Kedung Rejo Kecamatan Buay Madang Timur Kabupaten OKU Timur.

\section{Metode Pengolahan Data}

Data yang diperoleh dari penelitian akan dikelompokkan dan kemudian diolah menggunakan teknik komputerisasi dengan bantuan software microsoft excel yang akan ditampilkan dalam bentuk tabulasi sehingga dapat dijelaskan secara deskriptif.

a. Untuk mengetahui biaya produksi (Soekartawi, 2002), dengan rumus:

$$
\mathrm{TC}=\mathrm{FC}+\mathrm{VC}
$$

Dimana :

$\mathrm{TC}=$ Total Cost/Biaya Total Produksi (Rp/proses)

$\mathrm{FC}=$ Fixed Cost/Biaya Tetap (Rp/proses)

$\mathrm{VC}=$ Variabel Cost/Biaya Variabel (Rp/proses)

b. Untuk mengetahui penerimaan, digunakan rumus :

$$
\mathrm{TR}=\mathrm{Y} \times \mathrm{P}
$$

Dimana :

$\mathrm{TR}=$ Total Revenues/Penerimaan (Rp/proses)

$\mathrm{Y}=$ Yield/Hasil Produksi (Kg/proses)

$\mathrm{P}=$ Price/Harga Jual $(\mathrm{Rp} / \mathrm{Kg})$

c. Untuk menghitung pendapatan, digunakan rumus :

$$
\mathrm{I}=\mathrm{TR}-\mathrm{TC}
$$


Dimana :

$\mathrm{I}=$ Income/Pendapatan (Rp/proses)

$\mathrm{TR}=$ Total Revenue $/$ Penerimaan $(\mathrm{Rp} / \mathrm{proses})$

$\mathrm{TC}=$ Total Cost/Total Biaya Produksi (Rp/proses)

d. $\mathrm{R} / \mathrm{C}$ ratio dihitung dengan menggunakan rumus.

$\mathrm{R} / \mathrm{C}$ ratio $=\underline{\mathrm{TR}}$

$\mathrm{TC}$

Dimana :

$\mathrm{R} / \mathrm{C}=$ Return Cost Rasio

$\mathrm{TR}=$ Total Revenues/Penerimaan $(\mathrm{Rp} /$ proses $)$

$\mathrm{TC}=$ Total Cost $/$ Biaya Total (Rp/proses)

Dengan ketentuan :

R/C Ratio > 1 Berarti usahatani menguntungkan

$\mathrm{R} / \mathrm{C}$ Ratio $=1$ Berarti usahatani tidak untung dan tidak rugi (impas)

$\mathrm{R} / \mathrm{C}$ Ratio < 1 Berarti usahatani tidak menguntungkan (rugi)

e. Untuk menghitung NPV maka digunakan rumus :

$$
N P V=\sum \quad \frac{B t-C t}{(1+i)^{n}}-K o
$$

Dimana :

$\mathrm{NPV}=$ Net Present Value

Ko $=$ Kapital yang digunakan pada periode investasi.

$\mathrm{Bt}=$ Penerimaan pada tahun ke-t.

$\mathrm{Ct}=$ Pengeluaran discount faktor (bunga bank).

Dengan kriteria :

NPV > 0 maka usaha layak (feasible)

NPV < 0 maka usaha tidak layak untuk dilaksanakan

NPV $=0$ maka usaha dalam keadaan impas

f. Untuk menghitung Internal Rate Ratio (IRR) maka digunakan rumus :

$$
I R R=i_{1}+\frac{\dot{N} P V_{1}}{\left(N P V_{1-N P V_{2}}\right.} \times\left(i_{2}-i\right)
$$

Dimana :

$\mathrm{NPV}_{1}=\mathrm{NPV}$ pada tingkat discount rate tertinggi (positif).

$\mathrm{NPV}_{2}=\mathrm{NPV}$ pada tingkat discount rate terendah (negatif).

$\mathrm{i}_{1}=$ Discount rate tertinggi

$\mathrm{i}_{2} \quad=$ Discount rate terendah

Dengan kriteria :

IRR > Cost of Capital maka layak.

IRR < Cost of Capital maka tidak layak.

g.Untuk menghitung nilai net $\mathrm{B} / \mathrm{C}$ ratio maka digunakan rum

Net $\mathrm{B} / \mathrm{C}=$

$\underline{\Sigma \mathrm{NB}(+)}$

Dimana :

$$
\Sigma \mathrm{NB}(- \text { ) }
$$

$\Sigma$ NB (+) = Neı Deneıı yang telah didiscount positif
$\Sigma$ NB (+) $=$ Net Benefit yang telah didiscount negatif

Dengan kriteria :

Net B/C > 1 Berarti usahatani menguntungkan/ layak dikembangkan

Net $\mathrm{B} / \mathrm{C}=1$ Berarti usahatani tidak untung dan tidak rugi (impas)

Net $\mathrm{B} / \mathrm{C}<1$ Berarti usahatani tidak menguntungkan (rugi)

\section{HASIL DAN PEMBAHASAN}

\section{A. Analisa Biaya Budidaya Ikan Gurami}

Analisa biaya dilakukan sebagai tolak ukur suatu usaha apakah menguntungkan atau tidak dan apakah usaha tersebut layak untuk dikembangkan atau tidak. Untuk menganalisa usaha adalah dengan menghitung besarnya biaya produksi yang dikeluarkan, produksi ikan gurami yang dihasilkan, penerimaan dan pendapatan yang diperoleh oleh responden. Dalam penelitian biaya yang digunakan adalah biaya per proses produksi (15 bulan).

\section{Biaya Produksi Budidaya Ikan Gurami}

Total biaya adalah semua biaya yang digunakan dalam usaha budidaya ikan gurami yang meliputi biaya tetap dan biaya variabel. Biaya tetap adalah biaya yang besarnya tidak dipengaruhi oleh jumlah produksi, yang meliputi biaya sewa tempat yaitu sebesar Rp 1.200.000,00 per proses dan biaya penyusutan peralatan sebesar Rp 852.607,00 per proses, sehingga total biaya tetap yang dikeluarkan adalah sebesar $\mathrm{Rp}$ 2.052.607,00 per proses.

Biaya variabel adalah biaya yang besar kecilnya tergantung kepada besar kecilnya produksi dan akan habis dalam satu kali proses produksi. Biaya variabel dalam usaha budidaya ikan gurami meliputi biaya saprodi dan tenaga kerja. Adapun biaya sarana produksi (saprodi) meliputi : pembelian benih ikan gurami, pupuk kandang, vitamin untuk ikan dan pembelian pakan (pellet) yaitu sebesar Rp 13.592 .900 per proses. Besarnya biaya tenaga kerja yang digunakan dari awal proses budidaya sampai dengan panen yaitu sebesar Rp 3.671.000,00 per proses sehingga total biaya variabel yang terdiri dari biaya saprodi dan tenaga kerja adalah sebesar Rp 17.264.060,00 per proses.

Rata- rata besarnya biaya total produksi usaha budidaya ikan gurami yang terdiri atas biaya tetap dan biaya variabel adalah sebesar Rp 19.316.827 per proses produksi (15 bulan). Besarnya biaya yang dipergunakan pada usaha 
budidaya ikan gurami dapat dilihat pada tabel berikut.

Tabel 1. Rata-rata Biaya Produksi Usaha Budidaya Ikan Gurami di Desa Kedung Rejo Kecamatan Buay Madang Timur Kab OKU Timur, 2015.

\begin{tabular}{lr}
\hline No Uraian & \multicolumn{1}{c}{ Rp/Proses } \\
\hline 1. Total Biaya Tetap & $\mathbf{2 . 0 5 2 . 6 0 7 , 0 0}$ \\
a. Sewa Tempat & $1.200 .000,00$ \\
b. Penyusutan Peralatan & $852.607,00$ \\
2. Total Biaya Variabel & $\mathbf{1 7 . 2 6 7 . 0 6 0 , 0 0}$ \\
a. Biaya Sarana Produksi & $13.592 .900,00$ \\
b. Tenaga Kerja & $3.671 .000,00$ \\
3. Total Biaya Produksi & $\mathbf{1 7 . 2 6 4 . 0 6 0 , 0 0}$
\end{tabular}

Sumber : Hasil Olahan Data Primer, 2014.

\section{Penerimaan dan Pendapatan}

Penerimaan merupakan perkalian antara total produk yang terjual dengan harga persatuan produk. Penerimaan usaha ikan gurami semua berasal dari ikan gurami yang terjual. Ikan gurami yang dijual responden rata-rata dipanen setelah 15 bulan. Lebih jelasnya mengenai jumlah produksi, harga dan penerimaan dari usaha budidaya ikan gurami di Desa Kedung Rejo Kecamatan Buay Madang Timur dapat dilihat pada Tabel 2 berikut :

Tabel 2. Produksi, Harga, Penerimaan dan Pendapatan Usaha Budidaya Ikan Gurami di Desa Kedung Rejo Buay Madang Timur OKU Timur, 2015.

\begin{tabular}{|l|c|c|c|c|c|c|}
\hline No & $\begin{array}{c}\text { Produksi } \\
(\mathrm{Kg} / \mathrm{Lg} / \mathrm{PP})\end{array}$ & $\begin{array}{c}\text { Harga } \\
(\mathrm{Rp} / \mathrm{Kg})\end{array}$ & $\begin{array}{c}\text { Biaya Produksi } \\
\text { (Rp/LgP) }\end{array}$ & $\begin{array}{c}\text { Penerimaan } \\
(\mathrm{Rp} / \mathrm{Lg} / \mathrm{PP})\end{array}$ & $\begin{array}{c}\text { Pendapatan } \\
(\mathrm{Rp} / \mathrm{Lg} \mathrm{PP})\end{array}$ & $\begin{array}{c}\mathrm{RC} \\
\text { Rasio }\end{array}$ \\
\hline 1. & 1.246 & 28.133 & 19.316 .827 & 35.020 .333 & 15.703 .507 & 1,77 \\
\hline
\end{tabular}

Sumber : Hasil Olahan Data Primer, 2014.

Pada tabel diatas menunjukkan bahwa ratarata produksi ikan gurami untuk satu kali proses produksi (15 bulan) menghasilkan 1.246,00 $\mathrm{Kg} / \mathrm{Lg}$ atau dengan harga rata-rata $\mathrm{Rp}$ $28.133,00 / \mathrm{Kg}$ sehingga akan menghasilkan penerimaan rata-rata dalam satu kali proses produksi adalah sebesar Rp 35.020.333,00/Lg. Adapun rata-rata luas garapan (kolam) yang diusahakan adalah seluas $160 \mathrm{~m}^{2}$.

Pendapatan atau keuntungan yang diperoleh dari usaha budidaya ikan gurami merupakan selisih antara penerimaan dengan biaya total. Nilai pendapatan ini merupakan hasil bersih yang diperoleh selama proses produksi. Rata-rata penerimaan ikan gurami daun adalah sebesar $\mathrm{Rp}$ $35.020 .333,00 / \mathrm{Lg}$. Biaya produksi ikan gurami adalah sebesar Rp 19.316.827,00/Lg/Proses. sehingga dalam satu kali proses produksi (15 bulan) akan diperoleh rata-rata pendapatan sebesar Rp 15.703.507/Lg atau akan diperoleh pendapatan sebesar Rp 1.046.900/Bulan.

Hasil perhitungan analisis keuntungan diperoleh nilai $\mathrm{R} / \mathrm{C}$ rasio usaha budidaya ikan gurami dalam satu kali proses produksi adalah sebesar 1,77 yang berarti dalam setiap Rp 1 yang dikeluarkan untuk modal usaha budidaya ikan gurami maka akan dihasilkan penerimaan sebesar Rp 1,77. Nilai R/C yang lebih dari 1 ini menunjukan bahwa usaha budidaya ikan gurami yang dilakukan oleh petani ikan di Desa Kedung Rejo Kecamatan Buay Madang Timur cukup menguntungkan.

\section{B. Analisa Kelayakan Usaha Budidaya Ikan Gurami.}

\section{Analisa NPV}

Net Present Value (NPV) atau nilai sekarang bersih adalah analisis manfaat finansial yang digunakan untuk mengukur layak tidaknya suatu usaha dilaksanakan dilihat dari nilai sekarang (present value). Keuntungan dari suatu proyek adalah besarnya penerimaan dikurangi pembiayaan yang dikeluarkan. Dapat dikatakan bahwa NPV adalah selisih antara Present Value dari arus Benefit dikurangi Present Value dari arus biaya (Soekartawi, 1996). Dalam kriteria ini dikatakan bahwa proyek akan dipilih apabila nilai NPV lebih besar dari nol. Kesimpulannya jika suatu proyek mempunyai NPV kurang dari nol, maka tidak akan dipilih atau tidak layak untuk dijalankan atau proyek layak jika NPV bertanda positif dan sebaliknya tidak layak jika NPV bertanda negatif.

Tabel 3. Analisa NPV Usaha Budidaya Ikan Gurami di Desa Kedung Rejo Kecamatan Buay Madang Timur OKU Timur, 2015.

\begin{tabular}{|c|c|c|c|c|c|c|}
\hline \multicolumn{7}{|c|}{ TAHUN } \\
\hline No & Uraian & to & $\mathrm{tl}$ & 2 & t3 & t4 \\
\hline 1 & Penerimaan & & 35.020 .333 & 37.471 .757 & 40.094 .780 & 42.901.414 \\
\hline \multirow[t]{3}{*}{2} & Biaya-biaya & & & & & \\
\hline & a. Investasi Awal & 26.472 .500 & & & & \\
\hline & b. Total Biaya Produksi & & 19.316 .827 & 20.282 .668 & 21.499 .628 & 22.789 .606 \\
\hline 3 & Pendapatan & -26.472 .500 & $15.703 .506,67$ & $17.189 .088,67$ & 18.595 .152 & 20.111 .808 \\
\hline 4 & df at $18 \%$ & 1,00 & 0,85 & 0,72 & 0,61 & 0,52 \\
\hline \multirow[t]{2}{*}{5} & NPV at $18 \%$ & -26.472 .500 & 13.308 .056 & 12.344 .936 & 11.317 .583 & 10.373 .447 \\
\hline & TotalNPV & 20,871,522,71 & & & & \\
\hline
\end{tabular}

Sumber : Olahan Data Primer, 2014. 
Hasil analisis pada tabel diatas diperoleh nilai investasi awal untuk pembelian lahan dan alat-alat produksi adalah sebesar Rp 26.472.500,00 sehingga pendapatan pada tahun ke 0 adalah Rp -26.472.5006,00. Dari perhitungan NPV selama empat tahun dengan tingkat bunga $18 \%$ maka diperoleh nilai NPV adalah sebesar Rp 20.871.522,71 dan nilai NPV > 0, dengan pengertian usaha budidaya ikan gurami ini menguntungkan dan layak untuk dikembangkan.

\section{Analisa IRR (Internal Rate of Return)}

IRR menunjukkan kemampuan suatu investasi atau usaha dalam menghasilkan return atau tingkat keuntungan yang bisa dipakai. Kriteria yang dipakai untuk menunjukkan bahwa suatu usaha layak dijalankan adalah jika nilai IRR lebih besar dari tingkat suku bunga yang berlaku pada saat usahatani tersebut diusahakan (Gittinger, 1993). Jadi, jika IRR lebih tinggi dari tingkat bunga bank, maka usaha yang direncanakan atau yang diusulkan layak untuk dilaksanakan.

Tabel 4.Analisa Perhitungan IRR Usaha Budidaya Ikan Gurami di Desa Kedung Rejo Kecamatan Buay Madang Timur OKU Timur, 2015.

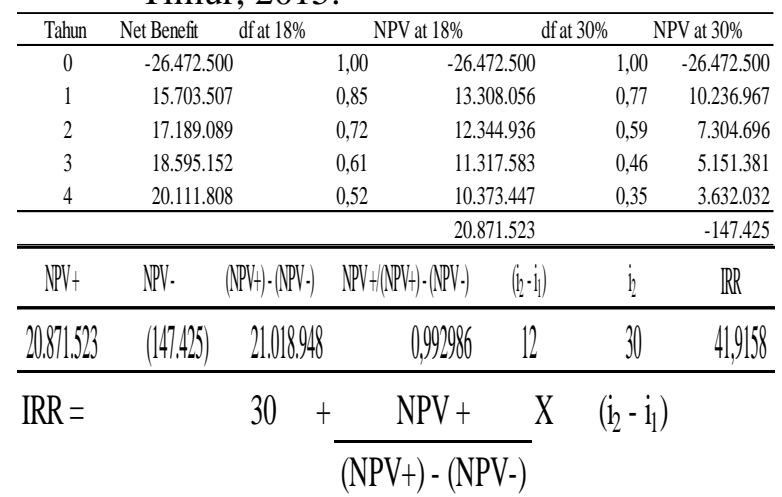

$\begin{aligned} \text { IRR } & =\quad 30+\frac{20.871 .523}{21.018 .948} \times 30-12 \\ & =\quad 30+0,992986 \times 12 \\ & =\quad 41,9158\end{aligned}$

Sumber : Olahan Data Primer, 2014.

Berdasarkan hasil perhitungan, diperoleh nilai IRR adalah sebesar 41,91 yang berarti nilai IRR > nilai suku bunga bank (SOCC) sebesar 18\%. Hal ini menunjukan bahwa usaha budidaya ikan gurami di Desa Kedung Rejo Kecamatan
Buay Madang Timur menguntungkan dan layak (feasible) untuk dikembangkan.

\section{Analisa Net $\mathrm{B} / \mathrm{C}$}

Benefit Cost Ratio adalah penilaian yang dilakukan untuk melihat tingkat efisiensi penggunaan biaya berupa perbandingan jumlah nilai bersih sekarang yang positif dengan jumlah nilai bersih sekarang yang negatif, atau dengan kata lain Net B/C adalah perbandingan antara jumlah NPV positif dangan jumlah NPV negatif dan ini menunjukkan gambaran berapa kali lipat benefit akan kita peroleh dari cost yang kita keluarkan. Kriteria ini memberikan pedoman bahwa suatu proyek akan dipilih apabila nilai ( $\mathrm{Net}$ $B / C>1)$, sebaliknya bila suatu proyek memberikan nilai (Net B/C $<1)$, maka proyek tidak akan diterima (diteruskan).

$$
\begin{aligned}
\text { Net B/C } & =\frac{\sum\left((\mathrm{B}-\mathrm{C}) /(1+\mathrm{i})^{\mathrm{t}}\right)(+)}{\sum\left((\mathrm{B}-\mathrm{C}) /(1+\mathrm{i})^{\mathrm{t}}\right)(-)} \\
& =\frac{47.344 .023}{26.472 .500} \\
& =1,79
\end{aligned}
$$

Hasil perhitungan, diperoleh nilai Net $\mathrm{B} / \mathrm{C}$ sebesar 1,79 , nilai $\mathrm{Net} \mathrm{B} / \mathrm{C}>1$ berarti usaha budidaya ikan gurami menguntungkan dan layak dikembangkan. Nilai Net B/C tersebut memiliki arti bahwa setiap Rp. 1,00 yang dikorbankan untuk budidaya ikan gurami maka akan meraih keuntungan sebesar Rp 1,79. Berdasarkan perhitungan analisa NPV, IRR dan Net B/C menunjukan bahwa usaha budidaya ikan gurami di Desa Kedung Rejo Kecamatan Buay Madang Timur Kabupaten OKU Timur menguntungkan dan layak (feasibel) untuk dikembangkan.

\section{IV.KESIMPULAN DAN SARAN}

\section{A. Kesimpulan}

Berdasarnya hasil penelitian dan analisis yang telah dilakukan, maka dapat ditarik kesimpulan sebagai berikut:

1. Biaya total produksi yang dikeluarkan dalam budidaya ikan gurami adalah sebesar $\mathrm{Rp}$ 19.316.827,00 per proses, penerimaan selama satu kali proses produksi sebesar Rp 35.020.333,00 sehingga pendapatan yang diterima adalah sebesar Rp 15.703.507,00 per proses. Nilai $\mathrm{R} / \mathrm{C}$ rasio adalah sebesar 1,77 menunjukan usaha budidaya ikan gurami menguntungkan. 
2. Nilai NPV adalah sebesar Rp 20.871.523, nilai IRR adalah sebesar $42 \%$ dan nilai Net B/C adalah sebesar 1,79 yang menunjukkan usaha budidaya ikan gurami layak (feasible) untuk dikembangkan.

\section{B.Saran}

Saran yang dapat diberikan dari hasil penelitian yang telah dilakukan adalah : Untuk mengurangi biaya produksi pembelian pellet ikan dan mempercepat masa pemanenan ikan gurami, hendaknya petani ikan gurami lebih banyak lagi memberikan dan menambahkan makanan ikan yang berasal dari daun talas (lompong) dan sayursayuran hijau lainnya.

\section{DAFTAR PUSTAKA}

Anonim. 2011. Ikan Gurami. www.ikan gurami.wikipedia.co.id. Diakses tanggal 10 Oktober 2014.

Dinas Kelautan dan Perikanan. 2010. Indonesia dan Negara Asia. Dinas Kelautan dan Perikanan. http://www.dkp.go.id. Diakses pada 06 Oktober 2014.

Departemen Pertanian. 1997. Pola Agribisnis. Sriwijaya Post. Palembang.

Hernanto. 1996. Ilmu Usaha Tani. Penebar Swadaya. Jakarta.

Ibrahim, Yacob. 2009. Studi Kelayakan Bisnis. Rineka Cipta. Jakarta.

Kartasapoetra. 1996. Pengantar Ekonomi Produksi. Bina Aksara. Jakarta.

1998. Dasar-dasar Ilmu Usahatani. LP3ES. Jakarta.

Mosher. 1984. Menggerakan dan Membangun Pertanian. CV. Yasaguna. Jakarta.

Mubyarto. 1990. Pengantar Ekonomi Pertanian. LP3ES. Jakarta.
Sjarkowi, F. 2004. Manajemen Agribisnis. C.V. Baldad Grafiti Press. Palembang.

Sjarkowi, F. 2010. Manajemen Pembangunan Agribisnis. Baldad Grafiti Press. Palembang.

Sjarkowi dan M. Sufri, 2004. Manajemen Agribisnis. CV Baldad Grafiti Press. Palembang.

Sitanggang, M. 1999. Budidaya Ikan Gurami. Penebar Swadaya. Jakarta.

Soeharjo dan Patong. 2004. Sendi-Sendi Pokok Ilmu-Ilmu Sosial. Institute Pertanian Bogor.

Soekartawi. 1991. Prinsip Dasar Ekonomi Pertanian. Raja Grafindo Persada. Jakarta. . 2001. Analisis Usahatani. UI Press. Jakarta.

2002. Agribisnis, Teori dan Aplikasi. Raja Grafindo Persada. Jakarta.

2003. Analisis Usaha Tani. UI Press. Jakarta.

2006. Agribisnis Teori dan Aplikasinya. PT. Raja Grafindo Persada. Jakarta. 